\title{
Article \\ Chemical Composition of Fir, Pine and Thyme Essential Oils and Their Effect on Onion (Allium cepa L.) Seed Quality
}

\author{
Hanna Dorna ${ }^{1}$, Dorota Szopińska ${ }^{1}$ (D) Agnieszka Rosińska ${ }^{1, *(\mathbb{D})}$ and Romuald Górski ${ }^{2}$ \\ 1 Department of Phytopathology, Seed Science and Technology, Poznań University of Life Sciences, \\ Dąbrowskiego 159, 60-594 Poznań, Poland; hanna.dorna@up.poznan.pl (H.D.); \\ dorota.szopinska@up.poznan.pl (D.S.) \\ 2 Department of Entomology and Environmental Protection, Poznań University of Life Sciences, \\ Dąbrowskiego 159, 60-594 Poznań, Poland; romuald.gorski@up.poznan.pl \\ * Correspondence: agnieszka.rosinska@up.poznan.pl; Tel.: +48-61-846-63-81
}

check for updates

Citation: Dorna, H.; Szopińska, D.; Rosińska, A.; Górski, R. Chemical Composition of Fir, Pine and Thyme Essential Oils and Their Effect on Onion (Allium cepa L.) Seed Quality. Agronomy 2021, 11, 2445. https:// doi.org/10.3390/agronomy11122445

Academic Editor: Anna Kocira, Katarzyna Panasiewicz, Ewa Szpunar-Krok and Nikos Tzortzakis

Received: 29 October 2021

Accepted: 28 November 2021

Published: 30 November 2021

Publisher's Note: MDPI stays neutral with regard to jurisdictional claims in published maps and institutional affiliations.

Copyright: (c) 2021 by the authors. Licensee MDPI, Basel, Switzerland. This article is an open access article distributed under the terms and conditions of the Creative Commons Attribution (CC BY) license (https:// creativecommons.org/licenses/by/ $4.0 /)$.

\begin{abstract}
Botrytis allii and B. cinerea are important seed-transmitted pathogens of onion. The aim of this study was to determine the chemical compositions of fir, pine and thyme essential oils and evaluate their effects on the germination, vigour and health of onion seeds. Gas Chromatography/Mass Spectroscopy was used for the analysis of the oils' chemical compositions. Seed germination, vigour and health tests were performed on untreated seeds and on seeds treated with volatile compounds of the oils applied at a concentration of $0.2 \mu \mathrm{L} \mathrm{cm}{ }^{-3}$ for $6,12,24,48$ and $72 \mathrm{~h}$ or at a concentration of $0.4 \mu \mathrm{L} \mathrm{cm}^{-3}$ for 3, 6 and $12 \mathrm{~h}$. The main components of fir oil were bornyl acetate $(55.5 \%)$ and $\alpha$-pinene (15.6\%), pine oil contained mostly $\alpha$-pinene (35.5\%) and $\beta$-pinene $(18.6 \%)$, and thymol $(34.2 \%)$ and p-cymene (26.2\%) prevailed in thyme oil. Almost all treatments significantly reduced seed infestation with Alternaria alternata and Fusarium spp., and some effectively controlled Botrytis spp., however, seed health improvement was usually associated with deterioration of seed germination and vigour. Only treatment with fir oil at a concentration of $0.2 \mu \mathrm{L} \mathrm{cm}^{-3}$ for $6 \mathrm{~h}$ effectively controlled seed-borne pathogens and positively affected seed germination. Considering the beneficial effect of the oils on seed health, further studies are necessary in order to establish the optimal conditions for onion seed treatment.
\end{abstract}

Keywords: essential oils; Abies alba; Pinus sylvestris; Thymus vulgaris; onion; seeds

\section{Introduction}

Seeds infested with pathogenic fungi often are the main source of plant diseases. Alternaria porri (Ell.) Ciferri, Botrytis allii Munn (syn. Botrytis aclada Fresen.), B. cinerea Pers., Fusarium spp. and Stemphylium botryosum Wallr. are seed-borne pathogens of onion [1]. Botrytis allii and B. cinerea, which cause seedling damping off, gray mould, and neck rot, the most serious diseases of onion bulbs in temperate areas of the world, are frequently detected on onion seeds. Common onion seed contaminants also include Alternaria alternata ( $\mathrm{Fr}$.) Keissler and fungi from genus Fusarium. Alternaria alternata is a very common cosmopolitan species which, as a facultative parasite, may quickly change itself into a pathogenic one and accelerate the occurrence and intensity of disease on certain plants [2]. Several Fusarium species, primarily F. solani and some formae specialis of F. oxysporum, cause rotting of seeds and seedlings, rotting of roots, lower stems and crowns and rots of bulbs and tubers. They affect many different kinds of vegetables, flowers and field crops. The related diseases occur worldwide and cause severe losses by reducing stands and the growth and yield of infected plants [3].

Seeds are commonly treated with chemicals to prevent their decay after sowing or the damping-off of young seedlings, as well as to control further disease development in the field. However, according to the principles of organic farming, synthetic plant protection products should be replaced by alternative physical and biological methods, or 
by compounds of natural origin. Essential oils are volatile secondary plant metabolites which play important roles in the chemical defense systems of various plants [4]. The main components of essential oils are, in general, monoterpenes and sesquiterpenes, followed by diterpenes and phenylpropanoids. One essential oil may contain over 30 compounds; however, usually only a few of them are present in higher concentrations and responsible for biological activity. The chemical composition of essential oils depends on environmental factors, plant origin, plant age, growth stage, and the plant part used as the source of the oil $[5,6]$. According to numerous reports on silver fir (Abies alba Mill.) essential oil, $\beta$-pinene, $\alpha$-pinene, camphene, bornyl acetate, limonene and phellandrene are the most prevalent compounds [7,8]. Dominant compounds in Scotch pine (Pinus sylvestris L.) essential oil include $\alpha$-pinene, car-3-ene, $\alpha$-phellandrene, $\beta$-phellandrene and $\beta$-pinene $[6,9]$. Thyme (Thymus vulgaris L.) essential oil has been found to be rich in the active monoterpene phenols thymol and carvacrol and their corresponding monoterpene hydrocarbon precursors p-cymene and $\gamma$-terpinene $[5,10]$. Essential oils have been used in human medicine for ages, and their antimicrobial, antioxidant, anti-inflammatory and anticancer activities have been well documented [11]. Because of their antimicrobial and antioxidant properties, the possibilities of using essential oils as preservatives in food processing and storage $[12,13]$ and as agents for the control of pathogenic bacteria and fungi in plant production [14-16] have been also frequently studied.

The antibacterial and antifungal activities of thyme essential oil are especially well known and scientifically proven. Thyme oil effectively controlled Ralstonia solanacearum (bacterial wilt) on tomato [14], and inhibited growth of Alternaria alternata, Alternaria infectoria, Aspergillus flavus, Epicoccum nigrum and Fusarium poae isolated from wheat grains [15]. In in vitro assays, thyme oil showed high activity against the seed-borne pathogens Xanthomonas campestris pv. campestris, Clavibacter michiganensis subsp. michiganensis, Alternaria dauci and Botrytis aclada, and at $0.33 \%$ concentration reduced the percentage of seeds contaminated with fungi in blotter tests from 70\% to less than 10\% [17]. Tinivella et al. [18] observed that thyme oil reduced the symptoms caused by Colletotrichum lindemuthianum on beans, and to some extent controlled Ascochyta pisi on peas. In the experiment of Koch et al. [19], thyme oil showed some antifungal activity against Alternaria dauci and Alternaria radicina. Kritzinger et al. [20] proved that thyme oil could effectively control storage fungi associated with cowpea seeds, specifically Penicillium chrysogenum, Fusarium equiseti and $F$. oxysporum. Schmitt et al. [21] recommended eradication of Phoma valerianellae from lamb's lettuce seeds in organic farming via several alternative methods, including aerated steam, hot water, electron treatment and thyme oil $(0.1 \%)$ treatment.

The antimicrobial activity of fir and pine oils have been frequently reported as well, however, mostly with regard to bacteria and fungi pathogenic to humans. In the experiment of Garzoli et al. [22], fir essential oil showed the highest antibacterial activity against Acinetobacter bohemicus and Bacillus cereus among four tested oils. Moreover, the authors observed that the vapor phase of all tested essential oils was more active than liquid phase. Salamon et al. [23] reported high antifungal activity of essential oils from Thymus vulgaris and Abies alba. Fir essential oil displayed a remarkable selective antimycotic effect against a clinical strain of Candida albicans; however, it was less effective against bacteria. A similar result was obtained by Serban et al. [24], who found that fir essential oil significantly inhibited the growth of $C$. albicans colonies on agar, but was not effective against Escherichia coli and Staphylococcus aureus. Marjanovic-Balaban et al. [25] observed activity of A. alba essential oil against $C$. albicans as well as several bacteria. Lanzerstorfer et al. [26] observed that air-dispersed essential oils from lemon (Citrus limon) and silver fir significantly (40$60 \%$ ) decreased air contamination with fungal spores in hospital rooms. Motiejūnaite and Pečiulytė [27] also tested the bactericidal and fungicidal properties of $P$. sylvestris essential oil for air quality improvement, finding that pine essential oil showed high antibacterial activity against Rhodococcus sp. and Bacillus sp., significant activity against the yeast Candida lipolytica and yeast-like fungi Aureobasidium pullulans and Geotrichum candidum, and slight activity against the fungi Aspergillus niger, Stachybotrys chartarum and Aspergillus versicolor. 
Oyewole et al. [28] reported high activity of pine essential oil against Micrococcus luteus and Klebsiella pneumonia.

Compared with thyme essential oil, the possibility of using fir and pine essential oils against seed-borne fungi has hardly been investigated; however, it can be assumed on the basis of the frequently-reported antimicrobial activity of these oils that they might be promising control agents in plant protection. Therefore, the aim of this study was to determine the chemical composition of fir, pine and thyme essential oils and to evaluate their effects on the germination, vigour, and health of onion seeds.

\section{Materials and Methods}

\subsection{Materials}

The commercially produced onion seed sample used in our experiments, cv. Octavia, was obtained from TORSEED Seed Company in Torun.

The fir (Abies alba Mill.), pine (Pinus sylvestris L.) and thyme (Thymus vulgaris L.) essential oils applied for seed treatment were obtained from Avinacea-OIL Co. in Wrocław.

\subsection{Methods}

\subsubsection{Analysis of the Chemical Compositions of the Essential Oils}

Gas Chromatography /Mass Spectroscopy (GC/MS) GCQ (Thermo-Finnigan, USA) with RT-5 (Resteck) capillary column ( $20 \mathrm{~m}$ length, $0.18 \mathrm{~mm}$ ID) with $0.2 \mu \mathrm{m}$ film thickness was used for the analysis of the essential oils' chemical compositions. A split injection with a ratio 1:50 was applied and the volume of injected sample was $1 \mu \mathrm{L}$. The temperature programme for the analysis was as follows: $50{ }^{\circ} \mathrm{C}$ was maintained for $1 \mathrm{~min}$, then increased to $320^{\circ} \mathrm{C}$ at a heating rate $4{ }^{\circ} \mathrm{C} \mathrm{min}-1$. The flow rate of the carrier gas (high purity grade

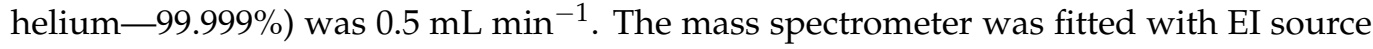
operated $70 \mathrm{eV}$; mass spectra were recorded in the range m/z 35-500 a.m.u. in the fullscan acquisition mode. Identification of the constituents was based on the comparison of their retention time and mass spectra with those of authentic samples, the NIST library data (National Institute of Standards and Technology, Gaithersburg, MD, USA), and the literature data [29]. Moreover, volatile compounds were identified by comparing their GC retention indices (RI) [30]. The percentage content of individual constituents of the essential oil was calculated based on the peak areas of every peak visible in the GM/MS chromatogram, which constituted the relative percentage content of the single terpene components in the essential oil and, when summed with other constituents, showed the total percentage of the identified components in the tested sample.

\subsubsection{Seed Treatment}

Seed germination, vigour, and health tests were performed for both untreated seeds (control) and seeds treated with volatile compounds of fir, pine and thyme essential oils. For treatment, $1 \mathrm{~g}$ of seeds was placed in a glass container with a $50 \mathrm{~cm}^{3}$ volume, and a 1 $\mathrm{cm}^{2}$ piece of filter paper imbibed with 10 or $20 \mu \mathrm{L}$ of fir, pine or thyme oil was hung over the seeds surface. Next, the containers were tightly closed with glass plugs and placed at $20^{\circ} \mathrm{C}$ in darkness for $6,12,24,48$ and $72 \mathrm{~h}$, when essential oils at the amount of $10 \mu \mathrm{L}$ were applied (concentration $0.2 \mu \mathrm{L} \mathrm{cm}^{-3}$ ), and for 3,6 and $12 \mathrm{~h}$ if the higher amount of oils was used (concentration $0.4 \mu \mathrm{L} \mathrm{cm}^{-3}$ ).

\subsubsection{Seed Germination Test}

Seed germination test was conducted according to International Seed Testing Association (ISTA) rules [31]. Six replications of 50 seeds for each treatment were tested. Seeds were placed in $9 \mathrm{~cm}$ diameter Petri dishes (50 seeds per dish) on six layers of blotter moistened with distilled water and incubated at $20^{\circ} \mathrm{C}$ in darkness. The percentages of normal seedlings were determined after 6 and 12 days of incubation (germination at the first and the final count). Moreover, after 12 days of incubation the percentages of abnormal diseased and deformed seedlings, dead seeds and fresh seeds were recorded. 


\subsubsection{Seed Vigour Test}

For vigour testing, six replications of 50 seeds from each treatment were incubated for 12 days in $9 \mathrm{~cm}$ diameter Petri dishes on six layers of blotter moistened with distilled water (50 seeds per dish) at $20^{\circ} \mathrm{C}$ in darkness. Germination parameters (i.e., $\mathrm{T}_{25}$ - time to $25 \%$ of the total number of germinating seeds $\left(\mathrm{G}_{\max }\right), \mathrm{T}_{75}$-time to $75 \%$ of $\mathrm{G}_{\max }, \mathrm{MGT}$-mean germination time, and $U_{75-25}$ - time between 25 and $75 \%$ of $\mathrm{G}_{\max }$ ) were determined on the basis of the number of seeds with a visible radicle, and counted daily.

\subsubsection{Seed Health Test}

To evaluate seed health, 200 seeds (four replications of 50 seeds) for each treatment were tested. Seeds were placed in $9 \mathrm{~cm}$ diameter Petri dishes (10 seeds per dish) on the surface of potato dextrose agar (PDA; $39 \mathrm{~g}$ PDA 1-1 distilled water $+100 \mathrm{ppm}$ of Streptomycin sulfate) and incubated at $20^{\circ} \mathrm{C}$ under a $12 \mathrm{~h}$ alternating cycle of NUV light and darkness for 10 days. After incubation, the fungi associated with the seeds were identified on the basis of their sporulation and colony appearance [32,33].

\subsubsection{Data Analysis}

SeedCalculator version 2.1. software [34] was applied to analyze seed vigour. All results were compared by means of variance analysis followed by the Duncan's multiple range test.

\section{Results}

\subsection{Chemical Compositions of the Essential Oils}

From the essential oil of $A$. alba, 17 components were identified, representing $99.9 \%$ of the total amount (Table 1). The dominant components were bornyl acetate $(57.5 \%)$ and $\alpha$-pinene $(15.6 \%)$, followed by limonene $(7.6 \%), \delta$-3-carene $(6.1 \%), \beta$-pinene $(4.4 \%)$ and camphene (3.5\%). In P. sylvestris oil, 23 components were detected, $99.5 \%$ of the total amount. Among them, $\alpha$-pinene (35.5\%), $\beta$-pinene (18.6\%), $\delta$-3-carene $(15.6 \%)$, limonene $(11.3 \%), \beta$-caryophyllene (5.3\%) and bornyl acetate (4.5\%) prevailed. From T. vulgaris oil 27 compounds were detected and identified, $99.9 \%$ of the total amount. The main components were thymol $(34.2 \%)$, p-cymene $(26.2 \%), 1,8$-cineole $(11.9 \%)$, limonene $(4.0 \%), \alpha$-pinene $(3.7 \%)$ and $\delta$-3-carene $(3.2 \%)$.

Table 1. Chemical composition of the essential oils of Abies, Pinus and Thymus species.

\begin{tabular}{ccccc}
\hline Components & $\begin{array}{c}\text { Abies } \\
\text { alba } \mathbf{( \% )}\end{array}$ & $\begin{array}{c}\text { Pinus } \\
\text { sylvestris } \mathbf{( \% )}\end{array}$ & $\begin{array}{c}\text { Thymus } \\
\text { vulgaris } \mathbf{( \% )}\end{array}$ & RI * \\
\hline santene & 0.2 & 0.1 & $-* *$ & 882 \\
tricyclene & 0.3 & 0.1 & - & 920 \\
-pinene & 15.6 & 35.5 & 3.7 & 931 \\
camphene & 3.5 & 1.3 & 0.1 & 946 \\
sabinene & - & 0.2 & - & 972 \\
$\beta$-pinene & 4.4 & 18.6 & 0.7 & 975 \\
$\beta$-myrcene & 0.2 & 1.5 & 0.2 & 993 \\
$\alpha$-phellandrene & - & 0.2 & 0.1 & 1005 \\
$\delta$-3-carene & 6.1 & 15.6 & 3.2 & 1010 \\
$\alpha$-terpinene & - & 0.4 & 0.1 & 1017 \\
p-Menth-3-ene & - & - & 0.1 & 1021 \\
p-cymene & 0.1 & 0.6 & 26.2 & 1025 \\
limonene & 7.6 & 11.3 & 6.0 & 1030 \\
1,8-cineole & 1.4 & - & 11.9 & 1060 \\
$\gamma$-terpinene & - & 0.1 & 0.2 & 1087 \\
isoterpinolene & - & 0.1 & - & 1090 \\
terpinolene & 1.0 & 3.0 & 0.1 & \\
\hline
\end{tabular}


Table 1. Cont.

\begin{tabular}{ccccc}
\hline Components & $\begin{array}{c}\text { Abies } \\
\text { alba } \mathbf{( \% )}\end{array}$ & $\begin{array}{c}\text { Pinus } \\
\text { sylvestris } \mathbf{( \% )}\end{array}$ & $\begin{array}{c}\text { Thymus } \\
\text { vulgaris } \mathbf{( \% )}\end{array}$ & RI * \\
\hline$\beta$-linalool & - & - & 0.5 & 1104 \\
camphor & 0.3 & - & - & 1147 \\
cis- $\beta$-terpineol & - & - & 0.1 & 1149 \\
isoborneol & - & - & 0.5 & 1159 \\
borneol & 0.3 & - & 2.0 & 1168 \\
$\alpha$-terpineol & 0.4 & 0.2 & 2.4 & 1198 \\
$\gamma$-terpineol & - & - & 0.7 & 1202 \\
linalyl acetate & - & - & 1.2 & 1259 \\
bornyl acetate & 57.5 & 4.5 & - & 1288 \\
thymol & - & - & 34.2 & 1301 \\
carvacrol & - & - & 2.5 & 1311 \\
cedr-8-ene & - & 0.1 & - & 1351 \\
$\alpha$-copaene & - & 0.1 & 0.1 & 1376 \\
longifolene & - & 0.1 & 0.2 & 1405 \\
$\beta$-caryophyllene & 0.9 & 5.3 & 2.6 & 1455 \\
$\alpha$-humulene & 0.1 & 0.6 & 0.2 & 1527 \\
$\delta$-cadinene & - & 0.1 & - & 1587 \\
caryophyllene & - & - & 0.1 & \\
oxide & & 99.5 & 99.9 & \\
\hline Total & 99.9 & & & \\
\hline
\end{tabular}

* Gas Chromatography retention indices; ${ }^{* *}$ not recorded.

\subsection{Seed Quality Evaluation}

\subsubsection{Seed Germination and Vigour}

The applied treatments did not generally affect the total number of germinating seeds $\left(G_{\max }\right)$. The increase in $\mathrm{G}_{\max }$ was observed only when thyme oil at concentrations of 0.2 and $0.4 \mu \mathrm{L} \mathrm{cm}^{-3}$ for $6 \mathrm{~h}$ was applied (Table 2). Treating seeds with fir oil at a concentration of $0.2 \mu \mathrm{L} \mathrm{cm}^{-3}$ for 6,12 and $72 \mathrm{~h}$, and with pine oil at a concentration of $0.2 \mu \mathrm{L} \mathrm{cm}^{-3}$ for $12 \mathrm{~h}$ significantly improved seed germination at the first count. On the other hand, germination both at the first and the final count decreased significantly when seeds were treated with pine oil at a concentration of $0.4 \mu \mathrm{L} \mathrm{cm}^{-3}$ for 6 and $12 \mathrm{~h}$, and with thyme oil at a concentration of $0.2 \mu \mathrm{L} \mathrm{cm}^{-3}$ for $24 \mathrm{~h}$, as well as at a concentration of $0.4 \mu \mathrm{L} \mathrm{cm}^{-3}$ for 3 and $12 \mathrm{~h}$. Moreover, deterioration of seed germination at the first count was recorded for seeds treated with fir oil at a concentration of $0.4 \mu \mathrm{L} \mathrm{cm}^{-3}$ for $6 \mathrm{~h}$, with pine oil at a concentration of $0.4 \mu \mathrm{L} \mathrm{cm}^{-3}$ for $3 \mathrm{~h}$, and with thyme oil at a concentration of $0.4 \mu \mathrm{L} \mathrm{cm}^{-3}$ for $6 \mathrm{~h}$. A decrease in seed germination at the final count was also observed for seeds treated with fir oil at a concentration of $0.4 \mu \mathrm{L} \mathrm{cm}^{-3}$ for $12 \mathrm{~h}$ and with thyme oil at a concentration of $0.2 \mu \mathrm{L} \mathrm{cm}{ }^{-3}$ for $72 \mathrm{~h}$.

Deterioration of seed germination was often associated with an increase in the number of abnormal, diseased, or/and deformed seedlings (Table 2). The percentage of diseased seedlings increased significantly in the case of seeds treated with pine oil at a concentration of $0.4 \mu \mathrm{L} \mathrm{cm}^{-3}$ for 6 and $12 \mathrm{~h}$, as well as when seeds were treated with thyme oil at the same concentration for $12 \mathrm{~h}$. However, the application of fir oil at a concentration of $0.4 \mu \mathrm{L} \mathrm{cm}^{-3}$ for $3 \mathrm{~h}$, and of thyme oil at a concentration of $0.2 \mu \mathrm{L} \mathrm{cm}^{-3}$ for $24 \mathrm{~h}$ and at a concentration of $0.4 \mu \mathrm{L} \mathrm{cm}^{-3}$ for 3 and $12 \mathrm{~h}$, resulted in a considerable increase in the percentage of abnormal deformed seedlings. The tested sample was characterized by a small number of dead and fresh seeds, 1.3 and $1.0 \%$ respectively, and the applied treatments did not affect the percentages of these seeds significantly (data not shown).

Deterioration of seed vigour, expressed by the significant increase in the values of all parameters characterizing speed of seed germination $\left(T_{25}, T_{75}, M G T\right)$, was observed when seed were treated with all essential oils at a concentration of $0.4 \mu \mathrm{L} \mathrm{cm}^{-3}$ for $6 \mathrm{~h}$, as well as with pine and thyme oils at a concentration of $0.2 \mu \mathrm{L} \mathrm{cm}^{-3}$ for $12 \mathrm{~h}$, and thyme oil at a concentration of $0.2 \mu \mathrm{L} \mathrm{cm}^{-3}$ for $72 \mathrm{~h}$ (Table 3). The application of fir oil at a concentration 
of $0.4 \mu \mathrm{L} \mathrm{cm} \mathrm{cm}^{-3}$ for $3 \mathrm{~h}$, pine oil at a concentration of $0.2 \mu \mathrm{L} \mathrm{cm}{ }^{-3}$ for $72 \mathrm{~h}$, and thyme oil at a concentration of $0.4 \mu \mathrm{L} \mathrm{cm}^{-3}$ for $12 \mathrm{~h}$ negatively affected only the parameter of time required to $25 \%$ germination, $G_{\max }$. Moreover, deterioration of the $T_{75}$ and MGT parameters was observed when fir oil at a concentration of $0.2 \mu \mathrm{L} \mathrm{cm}^{-3}$ was applied for 12 and for $72 \mathrm{~h}$, as well as when seeds were treated with thyme oil at the lower concentration for 24 and $48 \mathrm{~h}$. Mean germination time also increased if pine oil at a concentration of $0.2 \mu \mathrm{L} \mathrm{cm}{ }^{-3}$ was applied for $72 \mathrm{~h}$.

Table 2. The effect of essential oils on onion seed germination (\%).

\begin{tabular}{|c|c|c|c|c|c|c|c|c|c|c|c|c|}
\hline \multirow[b]{2}{*}{ Oil } & \multirow{2}{*}{$\begin{array}{l}\text { Concentration } \\
\left(\mu \mathrm{L} \mathrm{cm}^{-3}\right)\end{array}$} & \multirow{2}{*}{$\begin{array}{c}\text { Treatment } \\
\text { Duration } \\
\text { (h) }\end{array}$} & \multirow{2}{*}{\multicolumn{2}{|c|}{$\mathrm{G}_{\max } 1$}} & \multicolumn{4}{|c|}{ Germination } & \multicolumn{4}{|c|}{ Abnormal Seedlings } \\
\hline & & & & & First & ount & Final & ount & Dis & sed & Def & ned \\
\hline \multirow{8}{*}{ Fir } & & 6 & 96.7 & $a-e^{2}$ & 49.3 & jk & 80.0 & $\mathrm{kl}$ & 10.3 & $\mathrm{ab}$ & 7.7 & a \\
\hline & & 12 & 98.3 & $\mathrm{a}-\mathrm{e}$ & 54.3 & jk & 80.7 & 1 & 10.3 & a & 7.7 & $\mathrm{a}$ \\
\hline & 0.2 & 24 & 96.3 & $\mathrm{a}-\mathrm{e}$ & 45.0 & $g-j$ & 73.7 & $g-1$ & 11.7 & $\mathrm{a}-\mathrm{d}$ & 8.0 & $a b$ \\
\hline & & 48 & 96.7 & $\mathrm{a}-\mathrm{e}$ & 39.3 & $\mathrm{e}-\mathrm{h}$ & 67.3 & $\mathrm{~g}-1$ & 14.3 & $\mathrm{a}-\mathrm{f}$ & 11.0 & $\mathrm{ab}$ \\
\hline & & 72 & 93.3 & $\mathrm{a}$ & 50.0 & $\mathrm{jk}$ & 76.0 & $\mathrm{i}-1$ & 12.3 & $a-d$ & 8.3 & $\mathrm{a}-\mathrm{c}$ \\
\hline & & 3 & 98.0 & $\mathrm{c}-\mathrm{e}$ & 13.7 & $\mathrm{~b}$ & 63.3 & $b-f$ & 19.7 & $\mathrm{e}-\mathrm{h}$ & 14.0 & $c-g$ \\
\hline & 0.4 & 6 & 98.3 & $\mathrm{c}-\mathrm{e}$ & 20.7 & $\mathrm{bc}$ & 72.6 & $\mathrm{f}-1$ & 16.7 & $b-g$ & 7.0 & $a^{\circ}$ \\
\hline & & 12 & 97.3 & $\mathrm{a}-\mathrm{e}$ & 30.7 & $d-f$ & 66.0 & $\mathrm{~d}-\mathrm{h}$ & 17.3 & $\mathrm{c}-\mathrm{g}$ & 10.0 & a-e \\
\hline \multirow{8}{*}{ Pine } & & 6 & 97.3 & $a-e$ & 37.0 & e-h & 70.7 & $\mathrm{e}-\mathrm{j}$ & 15.3 & $a-f$ & 12.3 & a-f \\
\hline & & 12 & 97.7 & $\mathrm{a}-\mathrm{e}$ & 55.3 & $\mathrm{k}$ & 79.3 & $j-1$ & 11.7 & $\mathrm{a}-\mathrm{d}$ & 8.0 & $\mathrm{ab}$ \\
\hline & 0.2 & 24 & 96.7 & $\mathrm{a}-\mathrm{e}$ & 37.0 & $\mathrm{e}-\mathrm{h}$ & 68.7 & $\mathrm{e}-\mathrm{i}$ & 13.7 & $\mathrm{a}-\mathrm{e}$ & 11.7 & a-e \\
\hline & & 48 & 94.0 & $\mathrm{a}$ & 37.0 & $\mathrm{f}-\mathrm{i}$ & 73.7 & $\mathrm{e}-\mathrm{i}$ & 15.0 & $a-f$ & 8.0 & a-e \\
\hline & & 72 & 94.0 & $\mathrm{a}$ & 47.7 & $\mathrm{i}-\mathrm{k}$ & 75.3 & $\mathrm{~h}-1$ & 12.3 & $a-d$ & 7.7 & $\mathrm{a}$ \\
\hline & & 3 & 98.0 & $b-e$ & 15.7 & $\mathrm{~b}$ & 70.0 & $\mathrm{e}-\mathrm{i}$ & 17.3 & $\mathrm{c}-\mathrm{g}$ & 11.3 & a-e \\
\hline & 0.4 & 6 & 98.7 & $\mathrm{c}-\mathrm{e}$ & 20.7 & $\mathrm{c}-\mathrm{e}$ & 72.7 & $\mathrm{cg}$ & 16.7 & gh & 7.0 & $\mathrm{ab}$ \\
\hline & & 12 & 96.3 & $\mathrm{a}-\mathrm{e}$ & 15.0 & $\mathrm{~b}$ & 56.3 & $a-c$ & 29.3 & i & 10.0 & a-e \\
\hline \multirow{8}{*}{ Thyme } & & 6 & 99.0 & $\mathrm{e}$ & 46.7 & h-k & 76.0 & $\mathrm{i}-1$ & 11.3 & $a-c$ & 11.3 & a-e \\
\hline & & 12 & 96.3 & $\mathrm{a}-\mathrm{e}$ & 46.7 & h-k & 71.7 & $\mathrm{e}-\mathrm{k}$ & 15.7 & $a-f$ & 10.7 & a-e \\
\hline & 0.2 & 24 & 94.3 & $\mathrm{ab}$ & 27.0 & $\mathrm{~cd}$ & 64.0 & $\mathrm{~b}-\mathrm{e}$ & 15.0 & $a-f$ & 15.3 & e-g \\
\hline & & 48 & 97.0 & $\mathrm{a}-\mathrm{e}$ & 35.5 & $\mathrm{~d}-\mathrm{g}$ & 75.0 & $\mathrm{~h}-1$ & 14.7 & $a-f$ & 8.3 & $a-c$ \\
\hline & & 72 & 96.3 & $\mathrm{a}-\mathrm{e}$ & 34.7 & $d-f$ & 65.7 & $\mathrm{~d}-\mathrm{h}$ & 20.3 & e-h & 10.3 & a-e \\
\hline & & 3 & 96.0 & $\mathrm{a}-\mathrm{d}$ & 7.0 & a & 57.0 & $b-d$ & 17.7 & d-g & 23.0 & $\mathrm{~h}$ \\
\hline & 0.4 & 6 & 99.0 & de & 15.7 & $\mathrm{~b}$ & 67.0 & $\mathrm{e}-\mathrm{i}$ & 21.0 & $\mathrm{f}-\mathrm{h}$ & 9.3 & $\mathrm{a}-\mathrm{d}$ \\
\hline & & 12 & 98.0 & $\mathrm{~b}-\mathrm{e}$ & 6.0 & a & 47.7 & $\mathrm{a}$ & 25.3 & hi & 15.0 & d-g \\
\hline \multicolumn{3}{|c|}{ Control—untreated seeds } & 96.0 & $a-c$ & 38.3 & $\mathrm{f}-\mathrm{i}$ & 76.3 & $\mathrm{i}-1$ & 14.3 & $a-f$ & 7.0 & $\mathrm{a}$ \\
\hline
\end{tabular}

${ }^{1} \mathrm{G}_{\max }$ - total number of germinating seeds. ${ }^{2}$ Means in columns followed by the same letter are not significantly different at a level $\alpha=$ 0.05 , according to Duncan's multiple range test.

Table 3. The effect of essential oils on onion seed vigour (days).

\begin{tabular}{|c|c|c|c|c|c|c|c|c|c|c|}
\hline Oil & $\begin{array}{l}\text { Concentration } \\
\left(\mu \mathrm{L} \mathrm{cm}^{-3}\right)\end{array}$ & $\begin{array}{l}\text { Treatment } \\
\text { Duration } \\
\text { (h) }\end{array}$ & & & & & & & & \\
\hline \multirow{8}{*}{ Fir } & \multirow{5}{*}{0.2} & 6 & 2.42 & $a-d^{2}$ & 3.55 & $a-c$ & 3.19 & $a b$ & 1.13 & $a-c$ \\
\hline & & 12 & 2.59 & $b-f$ & 4.07 & gh & 3.41 & $b-f$ & 1.49 & de \\
\hline & & 24 & 2.30 & $\mathrm{a}$ & 3.64 & a-e & 3.00 & $\mathrm{a}$ & 1.34 & a-d \\
\hline & & 48 & 2.43 & $\mathrm{a}-\mathrm{e}$ & 3.68 & $a-f$ & 3.13 & $a b$ & 1.24 & $a-c$ \\
\hline & & 72 & 2.60 & $b-f$ & 3.91 & $d-g$ & 3.35 & $c-f$ & 1.30 & $a-d$ \\
\hline & \multirow{3}{*}{0.4} & 3 & 2.68 & $\mathrm{~d}-\mathrm{g}$ & 3.73 & $a-f$ & 3.25 & $a-e$ & 1.05 & $\mathrm{a}$ \\
\hline & & 6 & 2.62 & $\mathrm{c}-\mathrm{g}$ & 3.70 & $c-g$ & 3.34 & $b-f$ & 1.79 & $a-c$ \\
\hline & & 12 & 2.37 & $a-c$ & 3.57 & $a-c$ & 3.02 & $\mathrm{a}$ & 1.19 & $a-c$ \\
\hline
\end{tabular}


Table 3. Cont.

\begin{tabular}{|c|c|c|c|c|c|c|c|c|c|c|}
\hline \multirow{2}{*}{ Oil } & \multirow{2}{*}{$\begin{array}{l}\text { Concentration } \\
\qquad\left(\mu \mathrm{L} \mathrm{cm}^{-3}\right)\end{array}$} & \multirow{2}{*}{$\begin{array}{c}\text { Treatment } \\
\text { Duration } \\
\text { (h) }\end{array}$} & \multicolumn{2}{|c|}{$\mathrm{T}_{25}{ }^{1}$} & \multicolumn{2}{|c|}{$\mathbf{T}_{75}$} & \multicolumn{2}{|c|}{ MGT } & \multicolumn{2}{|c|}{$\mathrm{U}_{75-25}$} \\
\hline & & & 2.36 & $a b$ & 3.45 & $a b$ & 3.22 & $a-c$ & 1.08 & $a-c$ \\
\hline \multirow{7}{*}{ Pine } & \multirow{4}{*}{0.2} & 12 & 2.80 & $\mathrm{f}-\mathrm{h}$ & 4.13 & $g-i$ & 3.54 & $\mathrm{e}-\mathrm{g}$ & 1.33 & $a-d$ \\
\hline & & 24 & 2.53 & $\mathrm{a}-\mathrm{e}$ & 3.83 & $b-g$ & 3.20 & $a-d$ & $1, .31$ & $b-d$ \\
\hline & & 48 & 2.25 & $\mathrm{a}$ & 3.49 & $\mathrm{a}$ & 3.01 & $\mathrm{a}$ & 1.24 & a-d \\
\hline & & 72 & 2.78 & $\mathrm{f}-\mathrm{h}$ & 3.81 & $a-g$ & 3.32 & $b-f$ & 1.03 & $\mathrm{a}$ \\
\hline & \multirow{3}{*}{0.4} & 3 & 2.56 & $b-f$ & 3.70 & $a-f$ & 3.21 & $a-c$ & 1.14 & $\mathrm{ab}$ \\
\hline & & 6 & 2.73 & $\mathrm{f}-\mathrm{h}$ & 3.91 & $c-g$ & 3.36 & $b-f$ & 1.18 & $a b$ \\
\hline & & 12 & 2.38 & $a-c$ & 3.63 & $a-c$ & 3.02 & $\mathrm{a}$ & 1.25 & $a-c$ \\
\hline \multirow{8}{*}{ Thyme } & \multirow{5}{*}{0.2} & 6 & 2.47 & $\mathrm{a}-\mathrm{e}$ & 3.48 & $a b$ & 3.20 & $a-c$ & 1.01 & $\mathrm{a}$ \\
\hline & & 12 & 2.82 & $\mathrm{f}-\mathrm{h}$ & 4.24 & hi & 3.56 & $\mathrm{fg}$ & 1.42 & $\mathrm{~cd}$ \\
\hline & & 24 & 2.69 & $\mathrm{e}-\mathrm{g}$ & 4.42 & $\mathrm{i}$ & 3.71 & $\mathrm{~g}$ & 1.72 & $\mathrm{e}$ \\
\hline & & 48 & 2.62 & $\mathrm{e}-\mathrm{g}$ & 4.00 & $\mathrm{f}-\mathrm{h}$ & 3.48 & $\mathrm{~d}-\mathrm{g}$ & 1.33 & $a-d$ \\
\hline & & 72 & 2.99 & $\mathrm{~h}$ & 4.08 & gh & 3.73 & $\mathrm{~g}$ & 1.09 & $a b$ \\
\hline & \multirow{3}{*}{0.4} & 3 & 2.50 & $\mathrm{a}-\mathrm{e}$ & 3.57 & $a-c$ & 3.15 & $a b$ & 1.06 & $a b$ \\
\hline & & 6 & 2.92 & gh & 3.92 & $\mathrm{e}-\mathrm{h}$ & 3.48 & $c-g$ & 1.00 & $a b$ \\
\hline & & 12 & 2.64 & $c-g$ & 3.82 & $b-g$ & 3.27 & $\mathrm{a}-\mathrm{e}$ & 1.18 & $a-c$ \\
\hline \multicolumn{3}{|c|}{ Control-untreated seeds } & 2.34 & $\mathrm{ab}$ & 3.52 & $\mathrm{ab}$ & 2.96 & a & 1.18 & $\mathrm{a}-\mathrm{c}$ \\
\hline
\end{tabular}

${ }^{1} \mathrm{~T}_{25}$ - time to $25 \%$ of $\mathrm{G}_{\max }\left(\mathrm{G}_{\max }\right.$ - total number of germinating seeds); $\mathrm{T}_{75}$ - time to $75 \%$ of $\mathrm{G}_{\max }$; MGT-mean germination time; $\mathrm{U}_{75-25}$-time from 25 to $75 \%$ of $\mathrm{G}_{\max } \cdot{ }^{2}$ Means in columns followed by the same letter are not significantly different at a level $\alpha=0.05$, according to Duncan's multiple range test.

The applied treatments generally did not affect the uniformity of seed germination. Deterioration of the $U_{75-25}$ parameter was noted only for seeds treated with fir and thyme oils at the concentration of $0.2 \mu \mathrm{L} \mathrm{cm}^{-3}$ for 12 and $24 \mathrm{~h}$, respectively (Table 3).

\subsubsection{Seed Health}

Numerous fungi from sixteen genera, Alternaria, Aspergillus, Aureobasidium, Bipolaris, Botrytis, Cladosporium, Epicoccum, Fusarium, Melanospora, Mucor, Nigrospora, Penicillium, Rhizopus, Stemphylium, Trichoderma and Ulocladium, were identified on the onion seeds. Among these, Alternaria alternata (Fr.) Keissl., Botrytis allii Munn, B. cinerea Pers., Cladosporium spp. and Fusarium spp. were the most prevalent (Table 4).

Alternaria alternata was the most common seed contaminant, detected on $76.5 \%$ of untreated seeds. The applied treatments reduced the number of seeds infested with this fungus. The lowest level of infestation with A. alternata was in seeds treated with thyme oil at a concentration of $0.2 \mu \mathrm{L} \mathrm{cm}^{-3}$ for $24-72 \mathrm{~h}$ and at a concentration of $0.4 \mu \mathrm{L} \mathrm{cm}{ }^{-3}$ for 3 and $6 \mathrm{~h}$.

The pathogenic fungi $B$. allii and B. cinerea were identified on 18.0 and $13.0 \%$ of untreated seeds, respectively. The application of fir oil at a concentration of $0.2 \mu \mathrm{L} \mathrm{cm}^{-3}$ for 6 and $72 \mathrm{~h}$ and at a concentration of $0.4 \mu \mathrm{L} \mathrm{cm}^{-3}$ for 3,6 and $12 \mathrm{~h}$ significantly decreased seed infestation with $B$. allii. The decrease in the percentage of seeds infested with this fungus was observed also when thyme oil was applied at the lower concentration for 6 and $12 \mathrm{~h}$, and at the higher concentration for $3 \mathrm{~h}$. Moreover, a $60 \%$ decrease in seed infestation with B. allii was observed if pine oil at the higher concentration was applied for 3 and $6 \mathrm{~h}$; however, this reduction was not statistically significant.

All oils applied at a concentration of $0.4 \mu \mathrm{L} \mathrm{cm}^{-3}$, regardless of treatment time, efficiently controlled B. cinerea on onion seeds. Thyme oil was also effective at the lower concentration, irrespective of treatment time. In the case of fir and pine oil, the decrease in the number of seeds infested with this fungus was observed after the application of the former at a concentration of $0.2 \mu \mathrm{L} \mathrm{cm}^{-3}$ for 6 and $48 \mathrm{~h}$, and the latter for $6 \mathrm{~h}$. 
Table 4. The effect of essential oils on onion seed infestation with fungi.

\begin{tabular}{|c|c|c|c|c|c|c|c|c|c|c|c|c|}
\hline \multirow[b]{2}{*}{ Oil } & \multirow{2}{*}{$\begin{array}{l}\text { Concentration } \\
\left(\mu \mathrm{L} \mathrm{cm}^{-3}\right)\end{array}$} & \multirow{2}{*}{$\begin{array}{l}\text { Treatment } \\
\text { Duration } \\
\text { (h) }\end{array}$} & \multicolumn{10}{|c|}{ The Percentage of Seeds Infested with Fungi } \\
\hline & & & \multicolumn{2}{|c|}{$\begin{array}{c}\text { Alternaria } \\
\text { alternata }\end{array}$} & \multicolumn{2}{|c|}{$\begin{array}{c}\text { Botrytis } \\
\text { allii }\end{array}$} & \multicolumn{2}{|c|}{$\begin{array}{c}\text { Botrytis } \\
\text { cinerea }\end{array}$} & \multicolumn{2}{|c|}{$\begin{array}{c}\text { Cladosporium } \\
\text { spp. }\end{array}$} & \multicolumn{2}{|c|}{$\begin{array}{c}\text { Fusarium } \\
\text { spp. }\end{array}$} \\
\hline \multirow{8}{*}{ Fir } & & 6 & 68.5 & $\mathrm{~d}-\mathrm{f}^{1}$ & 3.5 & $\mathrm{a}$ & 3.0 & $\mathrm{a}-\mathrm{e}$ & 15.0 & $\mathrm{c}-\mathrm{g}$ & 1.5 & $\mathrm{ab}$ \\
\hline & & 12 & 69.0 & $\mathrm{~d}-\mathrm{f}$ & 11.5 & $\mathrm{~b}-\mathrm{i}$ & 5.0 & $b-f$ & 21.5 & $\mathrm{gh}$ & 2.0 & $\mathrm{ab}$ \\
\hline & 0.2 & 24 & 55.5 & $\mathrm{bc}$ & 9.0 & $a-g$ & 12.0 & ef & 35.0 & $\mathrm{i}$ & 4.0 & $\mathrm{~b}$ \\
\hline & & 48 & 63.0 & $\mathrm{~b}-\mathrm{e}$ & 16.5 & $\mathrm{f}-\mathrm{j}$ & 2.5 & $a-c$ & 19.0 & $\mathrm{f}-\mathrm{h}$ & 2.0 & $a b$ \\
\hline & & 72 & 58.0 & $b-d$ & 6.0 & $a-f$ & 5.5 & $c-f$ & 18.5 & $f-h$ & 2.5 & $a b$ \\
\hline & & 3 & 64.5 & $\mathrm{~b}-\mathrm{e}$ & 4.5 & $a b$ & 1,5 & $a-c$ & 9.0 & $a-e$ & 0.5 & $a$ \\
\hline & 0.4 & 6 & 59.0 & $\mathrm{~b}-\mathrm{e}$ & 6.0 & $a-f$ & 1.5 & $\mathrm{a}-\mathrm{d}$ & 14.5 & $\mathrm{c}-\mathrm{g}$ & 1.5 & $a b$ \\
\hline & & 12 & 67.5 & $c-f$ & 6.5 & $\mathrm{a}-\mathrm{e}$ & 0 & a & 5.5 & $\mathrm{ab}$ & 1.5 & $a b$ \\
\hline \multirow{8}{*}{ Pine } & & 6 & 64.0 & $\mathrm{~b}-\mathrm{e}$ & 8.0 & $a-h$ & 1.5 & $a-c$ & 19.5 & $\mathrm{f}-\mathrm{h}$ & 1.5 & $a b$ \\
\hline & & 12 & 60.0 & $\mathrm{~b}-\mathrm{e}$ & 17.0 & $g-j$ & 11.0 & $\mathrm{~d}-\mathrm{f}$ & 16.0 & $\mathrm{~d}-\mathrm{g}$ & 2.0 & $a b$ \\
\hline & 0.2 & 24 & 54.0 & $\mathrm{~b}$ & 9.5 & $\mathrm{~b}-\mathrm{i}$ & 5.5 & $b-f$ & 12.0 & $\mathrm{~b}-\mathrm{g}$ & 1.0 & $a b$ \\
\hline & & 48 & 53.5 & $\mathrm{~b}$ & 21.5 & $\mathrm{ij}$ & 4.0 & $b-f$ & 21.0 & gh & 2.0 & $a b$ \\
\hline & & 72 & 53.5 & $b$ & 15.0 & $\mathrm{e}-\mathrm{i}$ & 6.5 & $c-f$ & 17.0 & $\mathrm{~d}-\mathrm{g}$ & 1.5 & $a b$ \\
\hline & & 3 & 61.5 & $\mathrm{~b}-\mathrm{e}$ & 7.0 & $a-g$ & 1.5 & $a-c$ & 5.0 & $\mathrm{a}$ & 1.5 & $a b$ \\
\hline & 0.4 & 6 & 61.5 & $b-e$ & 7.5 & $a-g$ & 2.0 & $a-c$ & 11.5 & $b-g$ & 0 & $\mathrm{a}$ \\
\hline & & 12 & 71.5 & ef & 11.0 & $b-i$ & 2.5 & $a-d$ & 18.0 & $\mathrm{e}-\mathrm{h}$ & 1.5 & $a b$ \\
\hline \multirow{8}{*}{ Thyme } & & 6 & 65.5 & $b-f$ & 3.5 & $a-c$ & 0 & $\mathrm{a}$ & 13.5 & $c-g$ & 0.5 & a \\
\hline & & 12 & 54.0 & $\mathrm{~b}$ & 4.0 & $a-d$ & 0.5 & $\mathrm{ab}$ & 10.0 & $\mathrm{a}-\mathrm{f}$ & 0.5 & $\mathrm{a}$ \\
\hline & 0.2 & 24 & 38.5 & a & 9.5 & $b-i$ & 3.0 & $\mathrm{a}-\mathrm{e}$ & 15.5 & $\mathrm{~d}-\mathrm{g}$ & 1.0 & $a b$ \\
\hline & & 48 & 38.5 & a & 12.5 & $\mathrm{~b}-\mathrm{i}$ & 1.5 & $a-c$ & 10.0 & $a-f$ & 0.5 & $\mathrm{a}$ \\
\hline & & 72 & 28.5 & a & 19.0 & $h-j$ & 0.5 & $\mathrm{ab}$ & 21.0 & $\mathrm{gh}$ & 1.5 & $a b$ \\
\hline & & 3 & 38.5 & a & 4.5 & $a-d$ & 1.0 & $a-c$ & 7.0 & $a-c$ & 0 & a \\
\hline & 0.4 & 6 & 38.0 & $\mathrm{a}$ & 14.5 & $\mathrm{e}-\mathrm{i}$ & 3.0 & $a-d$ & 8.5 & $\mathrm{a}-\mathrm{d}$ & 0 & $\mathrm{a}$ \\
\hline & & 12 & 55.5 & $\mathrm{~b}-\mathrm{d}$ & 29.5 & $\mathrm{j}$ & 2.5 & $\mathrm{a}-\mathrm{d}$ & 28.0 & hi & 1.5 & $\mathrm{ab}$ \\
\hline \multicolumn{3}{|c|}{ Control—untreated seeds } & 76.5 & $\mathrm{f}$ & 18.0 & $\mathrm{~g}-\mathrm{j}$ & 13.0 & $\mathrm{f}$ & 21.0 & gh & 9.5 & c \\
\hline
\end{tabular}

${ }^{1}$ Means in columns followed by the same letter are not significantly different at a level $\alpha=0.05$, according to Duncan's multiple range test.

Fungi from the genus Cladosporium were identified on $21.0 \%$ of untreated onion seeds. The decrease in seed infestation with Cladosporium spp. was observed for seeds treated with fir oil at a concentration of $0.4 \mu \mathrm{L} \mathrm{cm}{ }^{-3}$ for 3 and $12 \mathrm{~h}$, with pine oil for $3 \mathrm{~h}$, and with thyme oil for 3 and $6 \mathrm{~h}$, as well as in the case of seeds treated with thyme oil at a concentration of $0.2 \mu \mathrm{L} \mathrm{cm}^{-3}$ for 12 and $48 \mathrm{~h}$. On the other hand, a significant increase in the percentage of seeds infested with Cladosporium spp. was found after the use of fir oil at a concentration of $0.2 \mu \mathrm{L} \mathrm{cm}{ }^{-3}$ for $24 \mathrm{~h}$.

Fusarium spp. were associated with 9.5\% of untreated seeds. All applied treatments significantly reduced infestation with these fungi or eliminated them from the seeds completely.

\section{Discussion}

The results of the present study revealed the high activity of thyme, fir and pine essential oils against fungi associated with onion seeds. Dorman and Deans [35], who analyzed the antimicrobial properties of several volatile essential oils as well as their individual components, found that the compound with the widest spectrum of activity was thymol, followed by carvacrol, $\alpha$-terpineol, terpinen-4-ol, eugenol, $( \pm)$-linalool, (-)-thujone, $\delta$-3-carene, cis-hex-3-an-1-ol, geranyl acetate, (cis+trans) citral, nerol, geraniol, menthone, $\beta$-pinene, $R(+)$-limonene, $\alpha$-pinene, $\alpha$-terpinene, borneol, $(+)$-sabinene, $\gamma$-terpinene, citronellal $\sim$ terpinolene, 1,8-cineole, bornyl acetate, carvacrol methyl ether, myrcene, $\beta$-caryophyllene, $\alpha$-bisabolol, $\alpha$-phellandrene, $\alpha$-humulene, $\beta$-ocimene, aromadendrene, and $p$-cymene. Ten of those compounds were the main components of oils used in our experiment. The dominant components of fir oil were bornyl acetate, $\alpha$-pinene, limonene, $\delta$ - 3 -carene, $\beta$-pinene 
and camphene, comprising $94.7 \%$ of the oil. In pine oil $\alpha$-pinene, $\beta$-pinene, $\delta$ - 3 -carene, limonene, $\beta$-caryophyllene and bornyl acetate were most prevalent, comprising $90.8 \%$ of the oil. The main components of thyme oil were thymol, p-cymene, 1,8-cineole, limonene, $\alpha$-pinene, $\delta$-3-carene, $\beta$-caryophyllene and carvacrol, comprising $88.8 \%$ of the oil. It has been found by several authors that essential oils containing high concentrations of phenolic compounds such as thymol, carvacrol and eugenol have the highest antimicrobial activity. These compounds are responsible for the disruption of the cytoplasmic membrane, the driving force of protons, electron flow, active transport, and the coagulation of cell contents [36]. Zambonelli et al. [37] investigated the influence of thyme oil and thymol on the hyphae cytomorphology of Fusarium solani (Mart.) Sacc., Rhizoctonia solani Kuhn and Colletotrichum lindemuthianum (Sacc. et Magn.) Briosi et Cav.) and observed vacuolization of the cytoplasm, accumulation of lipid bodies, undulations of the plasmalemma, and alterations of the mitochondria and endoplasmic reticulum. Soylu et al. [38] evaluated the contact and volatile phase effects of various essential oils towards the mycelial growth of Phytophthora infestans. The pathogen mycelium, when exposed to both phases of the oils, revealed considerable morphological changes in the hyphae, such as cytoplasmic coagulation, vacuolations, hyphal shriveling and protoplast leakage. In addition to the individual activity of essential oil components, a synergistic effect was also observed when a combination of substances was used. Some studies have shown that the use of the commercially available essential oils provides a better effect than the application of a mixture of major components. This suggests that minor components are also crucial for the activity of essential oils [36]. In the present experiment, all of the essential oil treatments effectively controlled Fusarium spp. on onion seeds, and frequently reduced their infestation with Botrytis spp. The efficacy of thyme oil against these fungi has been reported previously by several authors. Ben-Jabeur et al. [16] studied the potential of thyme essential oil in controlling gray mold and Fusarium wilt in tomato seedlings and tomato plants grown in a hydroponic system. The authors noted that this oil reduced colonization of pretreated detached leaves with Botrytis cinerea by $64 \%$ compared to the untreated control, and decreased Fusarium wilt (Fusarium oxysporum. f. sp. radicis lycopersici) severity on plants grown in a hydroponic system to 30.76\%. Kritzinger et al. [20] found that thyme oil effectively controlled fungi associated with cowpea seeds, specifically Penicillium chrysogenum, Fusarium equiseti and F. oxysporum, and did not negatively affect seed germination and plant emergence. Anzlovar et al. [15] found that fumigation of wheat grains with thyme essential oil significantly reduced seed infestation with Fusarium poae. Daferera et al. [39] observed inhibition of Fusarium solani var. coeruleum and B. cinerea growth on PDA medium with the addition of thyme oil, while in the experiment of Barrera-Necha et al. [40], thyme oil inhibited in vitro growth of Fusarium oxysporum f. sp. gladioli. In our experiment, almost all of the essential oil treatments significantly decreased the percentage of seeds infested with A. alternata; the highest level of reduction was observed for seeds treated with thyme oil at a concentration of $0.2 \mu \mathrm{L} \mathrm{cm}^{-3}$ for 24,48 and $72 \mathrm{~h}$ and at a concentration of $0.4 \mu \mathrm{L} \mathrm{cm}^{-3}$ for 3 and $6 \mathrm{~h}$. Results obtained by other authors confirm the effectiveness of thyme oil against Alternaria spp. In an in vitro experiment carried out by Feng and Zheng [41] and Feng et al. [12], thyme oil vapour appeared to be toxic to A. alternata, the fungus responsible for tomato fruit decay during storage. Moreover, Feng et al. [12] revealed in an in vivo experiment that fumigation with thyme oil at a concentration of $16.7 \mu \mathrm{L} / 1,33.3 \mu \mathrm{L} / 1$ and $66.7 \mu \mathrm{L} / 1$ reduced the percentage of decayed cherry tomatoes by $14.2 \%, 26.6 \%$ and $42.7 \%$ compared to the control, respectively, and was not phytotoxic to fruit. Soto-Mendivil et al. [42] found that thyme oil at a concentration of 1000 ppm effectively inhibited the growth of Alternaria citri on potato-dextrose-agar. In in vitro assays performed by Van der Wolf et al. [17], thyme oil showed high activity against seed-borne Alternaria dauci and Botrytis aclada, and at a $0.33 \%$ concentration reduced the percentage of seeds contaminated with these fungi in blotter tests from $70 \%$ to less than $10 \%$. Koch et al. [19] observed some antifungal activity of thyme oil against Alternaria dauci and Alternaria radicina, although it was less effective than physical seed treatment. Lopez-Reyes et al. [43] found that carrot 
seed treated with thyme essential oil, especially when combined with hot water dipping, effectively controlled the seed-borne pathogen Alternaria radicina. However, a mild phytotoxic effect was observed on the germination rate and the fresh biomass of carrot after this treatment. The antimicrobial potential of fir and pine oils has been previously reported, mostly in relation to bacteria and fungi pathogenic to humans $[5,23,24,26]$. Nevertheless, the results of our experiment revealed that both of them might also be successfully used for seed treatment.

It has been frequently proven that the most effective essential oils in pest control are also phytotoxic, and considerable precautions are required regarding their application [44]. According to Koch et al. [19], due to the inherent phytotoxicity of essential oils, choice of the optimal concentration is critical, and pre-testing is recommended. Anzlovar et al. [15] observed that direct soaking of wheat grain in thyme essential oil was particularly effective, but inhibited both fungal growth and seed germination. In contrast, fumigation inhibited fungal growth without negative effects on seedling development. The results of Ajayi et al. [45] showed that carvacrol, 1-8-cineole, and eugenol are phytotoxic to cowpea seeds. Mirmostafaee et al. [46]'s experiment confirmed that monoterpenes could affect the germination of seeds at very low concentrations. The authors found that essential oils of Thymus daenensis and Pimpinella anisum were among the strongest germination inhibitors. The results of our experiment confirmed this inhibitory effect of essential oils. Seeds treated with fir, pine and thyme oil generally showed lower vigour than untreated seeds. Moreover, deterioration of seed germination at the first count was frequently observed, especially when the oils were applied at higher concentrations. On the other hand, essential oil concentrations below the phytotoxic threshold could also stimulate plant growth and activate defense mechanisms against pathogens [44]; this has been demonstrated by phenolic compound and peroxidase activity measurements for thyme essential oil. Ben-Jabeur et al. [16] found that this oil triggers constitutive defense in tomato against gray mold and Fusarium wilt. The authors suggest that an increase in peroxidase activity resulting from oxidative burst (ROS) is a precursor of phenolic compound accumulation. In the present experiment, the applied treatments generally did not have a significant effect on seed germination, and even significantly improved seed germination at the first count when oils were applied with lower concentrations. This was recorded in the case of seeds treated for 6,12 and $72 \mathrm{~h}$ with fir oil, and $12 \mathrm{~h}$ with pine oil. Seeds treated with thyme oil at a concentration of $0.2 \mu \mathrm{L}$ $\mathrm{cm}^{-3}$ for 6 and $12 \mathrm{~h}$ were also characterized by higher germination at the first count than untreated seeds; however, this difference was not statistically significant.

\section{Conclusions}

The performed studies confirmed the antifungal properties of fir, pine and thyme essential oils. The reduction in seed infestation with Botrytis and Fusarium species, pathogenic or potentially pathogenic to onion, was frequently observed as a result of seed treatment. However, this was generally not connected with an improvement in seed germination. Only the treatment of seeds with fir oil at a concentration of $0.2 \mu \mathrm{L} \mathrm{cm}^{-3}$ for $6 \mathrm{~h}$ effectively controlled seed-borne pathogens while also positively affecting seed germination. Considering the beneficial effects of the applied oils on seed health, further studies are necessary in order to establish the optimal conditions for onion seed treatment. The selection of such appropriate treatment conditions as the concentration of essential oil and the treatment time may result in both the efficient control of seed-borne fungi and the improvement of seed germination. Another possibility is the use of a mixture of essential oils. Variability in the chemical composition of essential oils is caused by many uncontrollable factors, among them environmental conditions during the plant growth, and can affect their antimicrobial properties; therefore, the application of the individual components of the essential oils may be also considered. 
Author Contributions: Conceptualization, H.D. and D.S.; methodology and formal analysis H.D., A.R., D.S.; investigation and data curation, A.R., D.S., R.G.; writing-original draft preparation, D.S., R.G.; writing-review and editing, H.D., D.S., R.G. All authors have read and agreed to the published version of the manuscript.

Funding: The publication was co-financed within the framework of the Ministry of Science and Higher Education program as "Regional Initiative Excellence" in 2019-2022, Project No. 005/RID/2018/19, financing amount: 12,000,000 PLN.

Institutional Review Board Statement: Not applicable.

Informed Consent Statement: Not applicable.

Data Availability Statement: Not applicable.

Conflicts of Interest: The authors declare no conflict of interest.

\section{References}

1. Richardson, M.J. An Annotated List of Seed-borne Diseases, 4th ed.; International Seed Testing Association: Zürich, Switzerland, 1990; p. 351.

2. Kwaśna, H. Occurrence of Alternaria species in Poland. In Alternaria: Biology, Plant Diseases and Metabolites, 1st ed.; Chełkowski, J., Visconti, A., Eds.; Elsevier Science Publishers B.V.: Amsterdam, The Netherlands; London, UK; New York, NY, USA; Tokyo, Japanese, 1992; pp. 301-336.

3. Agrios, G.N. Plant Pathology, 4th ed.; Harcourt Academic Press: San Diego, CA, USA, 1997; p. 635.

4. El-Mohamedy, R.S.R. Plant Essential Oils for Controlling Plant Pathogenic Fungi. In Volatiles and Food Security, 1st ed.; Choudhary, D.K., Sharma, A.K., Agarwal, P., Varma, A., Tuteja, N., Eds.; Springer Nature: Singapore, 2017; pp. 171-198. [CrossRef]

5. Hudaib, M.; Speroni, E.; Di Pietra, A.M.; Cavrini, V. GC/MS evaluation of thyme (Thymus vulgaris L.) oil composition and variations during the vegetative cycle. J. Pharm. Biomed. Anal. 2002, 29, 691-700. [CrossRef]

6. Maciagg, A.; Milaković, D.; Christensen, H.H.; Antolović, V.; Kalemba, D. Essential oil composition and plant-insect relations in Scots pine (Pinus sylvestris L.). Food Chem. Biotechnol. 2007, 71, 71-95.

7. Chalchat, J.C.; Sidibé, L.; Maksimovic, Z.A.; Petrovic, S.D.; Gorunovic, M.S. Essential oil of Abies alba Mill., Pinaceae, from the pilot production in Montenegro. J. Essent. Oil Res. 2001, 13, 288-289. [CrossRef]

8. Ochocka, J.R.; Asztemborska, M.; Sybilska, D.; Langa, W. Determination of enantiomers of terpenic hydrocarbons in essential oils obtained from species of Pinus and Abies. Pharm. Biol. 2002, 40, 395-399. [CrossRef]

9. Judzentiene, A.; Kupcinskiene, E. Chemical composition on essential oils from needles of Pinus sylvestris L. grown in Northern Lithuania. J. Essent. Oil Res. 2008, 20, 26-29. [CrossRef]

10. Alexa, E.; Sumalan, R.M.; Danciu, C.; Obistioiu, D.; Negrea, M.; Poiana, M.A.; Rus, C.; Radulov, I.; Pop, G.; Dehelean, C. Synergistic antifungal, allelopathic and anti-proliferative potential of Salvia officinalis L., and Thymus vulgaris L. essential oils. Molecules 2018, 23, 185. [CrossRef] [PubMed]

11. Sharif-Rad, J.; Sureda, A.; Tenore, G.C.; Daglia, M.; Sharif-Rad, M.; Valussi, M.; Tundis, R.; Sharif-Rad, M.; Loizzo, M.R.; Ademiluyi, A.O.; et al. Biological activities of essential oils: From plant chemoecology to traditional healing systems. Molecules 2017, 22, 70. [CrossRef] [PubMed]

12. Feng, W.; Chen, J.; Zheng, X.; Liu, Q. Thyme oil to control Alternaria alternata in vitro and in vivo as fumigant and contact treatments. Food Control 2011, 22, 78-81. [CrossRef]

13. Omidbeygi, M.; Barzegar, M.; Hamidi, Z.; Naghdibadi, H. Antifungal activity of thyme, summer savory and clove essential oils against Aspergillus flavus in liquid medium and tomato paste. Food Control 2007, 18, 1518-1523. [CrossRef]

14. Abo-Elyousr, K.A.M.; Seleim, M.A.A.; Abd-El-Moneem, K.M.H.; Saead, F.A. Integrated effect of Glomus mosseae and selected plant oils on the control of bacterial wilt disease of tomato. Crop Prot. 2014, 66, 67-71. [CrossRef]

15. Anžlovar, S.; Likar, M.; Koce, J.D. Antifungal potential of thyme essential oil as a preservative for storage of wheat seeds. Acta Bot. Croat. 2017, 76, 64-71. [CrossRef]

16. Ben-Jabeur, M.; Ghabri, E.; Myriam, M.; Hamada, W. Thyme essential oil as a defense inducer of tomato against gray mold and Fusarium wilt. Plant Physiol. Biochem. 2015, 94, 35-40. [CrossRef] [PubMed]

17. van der Wolf, J.M.; Bimbaum, Y.; van der Zouwen, P.S.; Groot, S.P.C. Disinfection of vegetable seed by treatment with essential oils, organic acids and plant extracts. Seed Sci. Technol. 2008, 36, 76-88. [CrossRef]

18. Tinivella, F.; Hirata, L.M.; Celan, M.A.; Wright, S.A.I.; Amein, T.; Schmitt, A.; Koch, E.; van der Wolf, J.M.; Groot, S.P.C.; Stephan, D.; et al. Control of seed-borne pathogens on legumes by microbial and other alternative seed treatments. Eur. J. Plant Pathol. 2009, 123, 139-151. [CrossRef]

19. Koch, E.; Schmitt, A.; Stephan, D.; Kromphardt, C.; Jahn, M.; Krauthausen, H.J.; Forsberg, G.; Werner, S.; Amein, T.; Wright, S.A.I.; et al. Evaluation of non-chemical seed treatment methods for the control of Alternaria dauci and A. radicina on carrot seeds. Eur. J. Plant Pathol. 2010, 127, 99-112. [CrossRef] 
20. Kritzinger, Q.; Aveling, T.A.S.; Marasas, W.F.O. Effect of essential plant oils on storage fungi, germination and emergence of cowpea seeds. Seed Sci. Technol. 2002, 30, 609-619.

21. Schmitt, A.; Koch, E.; Stephan, D.; Kromphardt, C.; Jahn, M.; Krauthausen, H.-J.; Forsberg, G.; Werner, S.; Amein, T.; Wright, S.A.I.; et al. Evaluation of non-chemical treatment methods for the control of Phoma valerianellae on lamb's lettuce seeds. J. Plant Dis. Protect. 2009, 116, 200-207. [CrossRef]

22. Garzoli, S.; Masci, V.L.; Caradonna, V.; Tiezzi, A.; Giacomello, P.; Ovidi, E. Liquid and vapor phase of four conifer-derived essential oils: Comparison of chemical compositions and antimicrobial and antioxidant properties. Pharmaceuticals 2021, 14, 134. [CrossRef]

23. Salamon, I.; Kryvtsov, M.; Bucko, D.; Tarawneh, A.H. Chemical characterization and antimicrobial activity of some essential oils after their industrial large scale distillation. J. Microbiol. Biotechnol. Food Sci. 2019, 8, 984-988. [CrossRef]

24. Şerban, E.S.; Ionescu, M.; Matinca, D.; Maier, C.S.; Bojiţă, M.T. Screening of the antibacterial and antifungal activity of eight volatile essential oils. Pharmacia 2011, 59, 440-446.

25. Marjanovic-Balaban, Z.; Gojkovic Cvjetkovic, V.; Stanojevic, L.; Stanojevic, J.; Nikolic, L.; Danilovic, B. Quality testing of industrially produced essential oil of fir (Abies alba L.) from the Republic of Srpska. J. Essent. Oil-Bear. Plants 2020, 23, 503-513. [CrossRef]

26. Lanzerstorfer, A.; Hackl, M.; Schlömer, M.; Rest, B.; Deutsch-Grasl, E.; Lanzerstorfer, C. The influence of air-dispersed essential oils from lemon (Citrus limon) and silver fir (Abies alba) on airborne bacteria and fungi in hospital rooms. J. Environ. Sci. Health $A$ 2019, 54, 256-260. [CrossRef]

27. Motiejūnaitè, O.; Pečiulytè, D. Fungicidal properties of Pinus sylvestris L. for improvement of air quality. Medicina 2004, 40, 787-794.

28. Oyewole, K.A.; Oyedara, O.O.; Awojide, S.H.; Olawade, M.O.; Adetunji, C.O. Chemical constituents and antibacterial activity of essential oils of needles of Pinus sylvestris (Scots pine) from South West Nigeria. Res. Sq. 2021, 1-15. [CrossRef]

29. Adams, R.P. Identification of Essential Oils Components by Gas Chromatography/Mass Spectrometry, 4th ed.; Allured Publishing Corp.: Carol Stream, IL, USA, 2007; p. 804.

30. Skalicka-Wozniak, K.; Los, R.; Glowniak, K.; Malm, A. Comparison of hydrodistillation and headspace solid-phase microextraction techniques for antibacterial volatile compounds from the fruits of Seseli libanotis. Nat. Prod. Commun. 2010, 5, 1427-1430. [CrossRef]

31. International Rules for Seed Testing; International Seed Testing Association (ISTA): Bassersdorf, Switzerland, 2014.

32. Mathur, S.B.; Kongsdal, O. Common Laboratory Seed Health Testing Methods for Detecting Fungi; International Seed Testing Association: Bassersdorf, Switzerland, 2003.

33. Machado, J.C.; Langerak, C.J.; Jaccoud-Filho, D.S. Seed-borne Fungi: A Contribution to Routine Seed Health Analysis; International Seed Testing Association: Bassersdorf, Switzerland, 2002.

34. Jalink, H.; Van der Schoor, R. Seed Calculator 2.1. License Number: 100200122; Plant Research International: Wageningen, The Netherlands, 1999.

35. Dorman, H.J.D.; Deans, S.G. Antimicrobial agents from plants: Antibacterial activity of plant volatile oils. J. Appl. Microbiol. 2000, 88, 308-316. [CrossRef] [PubMed]

36. Dhifi, W.; Bellili, S.; Jazi, S.; Bahloul, N.; Mnif, W. Essential oils' chemical characterization and investigation of some biological activities: A critical review. Medicines (Basel) 2016, 3, 25. [CrossRef] [PubMed]

37. Zambonelli, A.; D'Aulerio, A.; Severi, A.; Benvenuti, S.; Maggi, L.; Bianchi, A. Chemical composition and fungicidal activity of commercial essential oils of Thymus vulgaris L. J. Essent. Oil Res. 2004, 16, 69-74. [CrossRef]

38. Soylu, E.M.; Soylu, S.; Kurt, S. Antimicrobial activities of the essential oils of various plants against tomato late blight disease agent Phytophthora infestans. Mycopathologia 2006, 161, 119-128. [CrossRef]

39. Daferera, D.J.; Ziogas, B.N.; Polissiou, M.G. The effectiveness of plant essential oils on the growth of Botrytis cinerea, Fusarium sp. and Clavibacter michiganensis subsp. michiganensis. Crop Prot. 2003, 22, 39-44. [CrossRef]

40. Barrera-Necha, L.L.; Garduno-Pizana, C.; Garcia-Barrera, L.J. In vitro antifungal activity of essential oils and their compounds on mycelial growth of Fusarium oxysporum f. sp. gladioli (Massey) Snyder and Hansen. Plant Pathol. J. 2009, 8, 17-21. [CrossRef]

41. Feng, W.; Zheng, X. Essential oils to control Alternaria alternata in vitro and in vivo. Food Control 2007, 18, 1126-1130. [CrossRef]

42. Soto-Mendívil, E.A.; Moreno-Rodríguez, J.F.; Estarrón-Espinosa, M.; García-Fajardo, J.A.; Obledo-Vázquez, E.N. Chemical composition and fungicidal activity of the essential oil of Thymus vulgaris against Alternaria Citri. e-Gnosis 2006, 4, 16.

43. Lopez-Reyes, J.G.; Gilardi, G.; Garibaldi, A.; Gullino, M.L. In vivo evaluation of essential oils and biocontrol agents combined with hot water treatments on carrot seeds against Alternaria radicina. J. Phytopathol. 2016, 164, 131-135. [CrossRef]

44. Werrie, P.Y.; Durenne, B.; Delaplace, P.; Fauconnier, M.L. Phytotoxicity of essential oils: Opportunities and constraints for the development of biopesticides. A review. Foods 2020, 9, 1291. [CrossRef] [PubMed]

45. Ajayi, O.E.; Appel, A.G.; Fadamiro, H.Y. Phytotoxicity of some essential oil components to cowpea (Vigna unguiculata (L.) Walp.) seeds. Int. J. Plant Biol. Res. 2014, 2, 1024.

46. Mirmostafaee, S.; Azizi, M.; Fujii, Y. Study of allelopathic interaction of essential oils from medicinal and aromatic plants on seed germination and seedling growth of lettuce. Agronomy 2020, 10, 163. [CrossRef] 